\title{
A Discourse Analysis of Denmark's Public Health Policy Concerning Overweight among Pregnant Women
}

\author{
Lene Toxvig1* $^{*}$, Carsten K. Bak ${ }^{2}$, Tine M. Kristiansen ${ }^{3}$ \\ ${ }^{1}$ Department of Midwifery, University College of Northern Jutland, Aalborg, Denmark \\ ${ }^{2}$ Department of Health, Science and Technology, Aalborg University, Aalborg, Denmark \\ ${ }^{3}$ Department of Sociology and Social Work, Aalborg University, Aalborg, Denmark \\ Email: ${ }^{*} \operatorname{lnt} @ u c n . d k$
}

How to cite this paper: Toxvig, L., Bak, C. K., \& Kristiansen, T. M. (2017). A Discourse Analysis of Denmark's Public Health Policy Concerning Overweight among Pregnant Women. Advances in Applied Sociology, 7, 227-244.

https://doi.org/10.4236/aasoci.2017.76014

Received: May 2, 2017

Accepted: June 9, 2017

Published: June 12, 2017

Copyright (c) 2017 by authors and Scientific Research Publishing Inc. This work is licensed under the Creative Commons Attribution International License (CC BY 4.0).

http://creativecommons.org/licenses/by/4.0/

\begin{abstract}
A recent Danish public health report classified being overweight during pregnancy as a chronic disease, marking a discursive shift from its previous classification as a risk factor for complications in maternal and foetal health. This discursive shift is considered a breach in the discursive field. Health care professionals' approach to governing overweight pregnant women is affected by this breach in the discursive field. Thus, overweight pregnant women have become an issue for medical experts, who are encouraged to use stricter rhetoric when addressing them. This shift also renders pregnant women subject to interventions by medical experts. The aim of this article is to critically analyse recommendations for how health professionals should govern these highrisk individuals and to discuss the implications of such governance for overweight pregnant women. In this study, overweight is classified as BMI $\geq 30$ and severe obesity is classified as BMI $\geq 35$ on the basis of pre-pregnancy weight. The theory of social construction and the concept of governmentality are applied in a discourse analysis of the prevention of overweight among pregnant women in Denmark. Using a discursive approach, this study analyses central governmental documents that discuss obesity prevention. Three forms of freedom (as discipline, as solidarity and as autonomy) are transferred to three forms of governing and constitute the conceptual framework. The main finding is that public health programmes encourage governing through solidarity, including a palette of autonomy-making, responsibility-making and disciplinary technologies, to promote physical health. Public health programmes conjure an image of overweight individuals as strongly burdened subjectivities. The implications for overweight pregnant women are the formation of new subjectivities, engagement in patient associations, the threat of exclusion from communities and social citizenship and other forms of stigmatization.
\end{abstract}




\section{Keywords}

Public Health Policy, Overweight, Pregnancy, Discourse Analysis, Forms of Governing

\section{Introduction}

When being overweight in pregnancy is addressed in the Danish health care system, the focus is on the prevalence and potential complications of the condition. The scientific health literature includes biomedical discourses on obesity in pregnancy. For example, the literature states that women often develop severe obesity during pregnancy (National Board of Health, 2006: p. 1) that one-third of pregnant women in Denmark are overweight, and that more than $12 \%$ are severely obese. Overweight is classified as BMI $\geq 30$ and severe obesity is classified as $\mathrm{BMI} \geq 35$ on the basis of pre-pregnancy weight. Being underweight (BMI < 18.5) in pregnancy is actually more dangerous than being overweight (Rahman et al., 2015: p. 758), but it is also more socially acceptable; this example draws attention to the discursive nature of the medical understanding of being overweight and disrupts the status of these "objective truths". Overweight is associated with several complications related to pregnancy and birth, including infertility, miscarriage, hypertension, preeclampsia and gestational diabetes, in addition to increased incidence of interventions such as labour induction, vacuum delivery and caesarean section (Danish Association of Obstetrics and Gynaecology [DSOG], 2012: p. 5). Relative to the general population, obesity is more frequent among women with less education, lower incomes and lower-skilled jobs (National Institute for Public Health, 2007: p. 267). A 2011 systematic review concluded that although numerous interventions have been attempted, none has had significant effects on weight gain during pregnancy (Campbell, Johnson, Messina, Guillaume, \& Goyder, 2011: p. 1). The Danish National Board of Health has called for research into methods and programmes to support changes in lifestyle that reduce weight gain among pregnant women (National Board of Health, 2013: p. 134). Obesity in pregnancy is an important issue not only in the field of Danish public health but also internationally. This issue was addressed in a review of antenatal interventions to reduce weight among obese pregnant women that primarily considered studies from Europe, North America, the Nordic countries, Australia and New Zealand (Furber et al., 2013: p. 7).

Biomedical discourses on overweight in pregnancy seem to adopt an almost solemn tone when focusing on the prevalence of the condition and the potential physical complications of overweight in pregnancy. In this article, our intention is to critique such discourses.

Overweight pregnant women characterize the medical profession's approach to them as lacking respect, engaging in moral condemnation and withholding important information (Lindhardt, Rubak, Mogensen, Lamont, \& Joergensen, 2013: p. 1101). Furthermore, in the experience of overweight pregnant women, 
persons in power do not always recognize the degrading attitudes and behaviour that these women face in health care (Malterud \& Ulriksen, 2011: p. 1). Hence, facilitating health professionals' awareness of their governing role is relevant for promoting reflection on their effects on overweight persons.

In some cases, overweight may entail altered concepts of disease and health. In Denmark, overweight was first defined as a chronic disease in The Public Health Report Denmark 2007: "Obesity is a chronic disease and should be treated as such with lifelong control and treatment" (National Institute for Public Health, 2007: p. 261). According to this report, there is an increased incidence of low self-esteem among the severely obese (National Institute for Public Health, 2007: p. 264). Low self-esteem among the severely obese might imply a reduced ability to act according to health care recommendations. Consequently, the active reaction of severely obese people to their condition depends on their inner resources to adhere to the dominant discourse. Our intention is to propose a critique of this biomedical discourse, focusing on individual responsibility being primarily expressed as a question of inner resources.

This study begins by considering official governmental documents, which form the background for the guidance that health professionals receive concerning overweight pregnant women. We argue that the categorization of this group in these documents has a decisive influence on health care practice and how this group of women is addressed in health care with reference to the scientific approach. The social construction of target groups becomes embedded in the policy design contained in the documents; hence, messages about the target group's worth and values are sent to society and the relevant institutions (Schneider \& Ingram, 2008: p. 195). This influences health care personnel's practices and attitudes towards the target group.

The aim of this article is to critically analyse official recommendations for health professionals' governance of these high-risk individuals and to discuss the possible implications of the governing approaches for overweight pregnant women, their social relationships and their relationship with themselves.

\section{Analytical Framework}

The analytical framework of this study is the relationship between governmentality and the specific types of subjects created through this governing. Foucault describes governmentality as follows: "This contact between technologies of domination of others and those of the self I call governmentality" (Foucault, 1988: p. 19). Governmentality is an expression of governance, which has the distinct purpose to "maximize the right order, safety, tranquillity, wealth, health and happiness of the subjects" (Rose, 2003: p. 181). In this context, subjectivity is understood as a non-essentialist way of perceiving human behaviour and experience (Foucault, 1982: p. 777), meaning that human beings develop as a result of the production, shaping and utilization of them as subjects. According to Foucault (1972a), power is exercised over free human beings who accept the government because it offers something desired: enjoyment, knowledge and new 
opportunities (p. 119). Governmentality is a mode of thinking and organizing practices directed against government. It involves a regulated process by which subjects are made autonomous and free-free not only to be governed but also to govern themselves (Perron, Rudge, \& Holmes, 2010: p. 105). The supposed consequences for the individual pregnant woman may be expressed in how subjects are formed through encouraging capacities and self-perceptions (Vallgårda, 2003b: p. 119).

Governmentality does not exclude techniques of repression or discipline, but includes the regulation of the self as an intricate part of the government of individuals. This means that conduct is achieved primarily through self-work and self-reflection. Foucault's work on governmentality implies freedom in a sense that makes the government of populations and individuals possible (Perron et al., 2010: p. 105). The government and production of responsible and autonomous citizens, using a governmentality framework, are all more or less rationalized attempts to modify a person's behaviour, individually or collectively, to achieve certain goals (Rose, 2003: p. 180). According to Rose, the health professional's exercise of power over the population involves imposing control over people. The interesting feature is not the exercise of power per se but how subjects are formed, along with the characteristics and self-perceptions that the exercise of power seems to encourage among the governed. To govern is both to presuppose that the capacity to act is not eliminated and to acknowledge and utilize that capacity for one's own purposes (Rose, 1999: p. 4). Governmentality concerns how subjects are objectivised and how they turn themselves into subjects (Foucault, 1982: pp. 777-778). Foucault understood government as a form of activity aiming to shape, guide or affect the conduct of subjects through the notion of freedom (Gordon, 1991: p. 2). The definition of the subject, as it relates to governmentality, concerns how subjects are produced and produce themselves through freedom. Rose describes three different forms of freedom: freedom as discipline, freedom as solidarity and freedom as autonomy (Rose, 1999: pp. 61-97). Despite the apparent paradox between freedom and governing, Rose argues that by their nature, human beings are subjects of freedom; as such, they must be governed and must govern themselves (Rose, 1999: p. 62). Hence, the three forms of freedom are transferred to three forms of governing, which will be presented in the following section.

Governing through discipline occurs when the authorities seek to capitalize on people's attempts to satisfy certain perceptions of normality. This strategy is consistent with what Rose (1998) describes as a shift from the prevention of maladaptation to the production of normality (p. 163). This technology seeks to instil the desired norms; thereby, governmentality at a distance is accomplished through the appeal to responsibility, self-discipline and self-control (Rose, 1999: p. 78). Governing through discipline is achieved through the technologies of the self. According to Rose (1998), moralizing discipline from the state bureaucracy is no longer needed (p. 162) because individuals in the new domain of consumption will wish to be healthy, happy, free, wealthy and safe, and experts will in- 
struct them on how to accomplish these goals.

Governing through solidarity occurs when the authorities make the individual feel responsible to a community. Authorities in the welfare state satisfy many of the citizens' needs and wishes, thereby legitimating directives from the authorities. The services of the welfare state, e.g., screenings of the population, are interpreted as part of the state's obligation to provide for the population's health. As a precondition, the population must behave responsibly in relation to individually chosen lifestyles. According to Rose (1999), the normal citizen must be a social inhabitant who is adapted to society and whose wishes are realized in society (p. 79). In this way of thinking, deviations from health-related norms are considered antisocial, and high-risk individuals are considered to have neglected their responsibility to the community; they have become "imprudent anti-citizens" (Rose, 2003: p. 194). When this thinking is applied to overweight pregnant women, they become carriers of a visible sign of not having satisfied expectations concerning health norms; hence, they are regarded as imprudent citizens.

Governing through autonomy is based upon the authorities governing individuals as autonomous human beings. Governing occurs by mediating the individual's ability to act in certain ways, by shaping the choices that the individual makes and by forming ideals (Rose, 1999: p. 84). Rose describes the active citizen as a normative ideal, which is constituted and manifested through the exercise of free personal choice among a variety of options. This requires health policy to use technologies that shape and govern subjects by promoting their social engagement. Citizens should be active, not passive, and a democratic government must engage individuals' self-activating capacity. Contemporary political rationalities use a range of technologies that install the civilizing project by enhancing subjects' social commitment (Rose, 1998: p. 165). Health-promoting capacity is activated through networking, a preventive strategy known from the establishment of patient groups, care teams, professional bodies and research groups. This way of governing encourages indirect mechanisms, confining the aims of health policy to affecting individual choices.

\section{The Danish Public Health System}

The Danish public health system is divided into three administrative and political levels: the state, five regions and 98 municipalities. Denmark's health care system is a tax-financed Beveridge-type system in which the state's role is to be responsible for overall financing and regulation. The 1942 Report on Social Insurance and Allied Services was an influential document in the founding of the welfare state in the UK. This report identified five 'huge evils' of society: poverty, ignorance, want, idleness and disease. It proposed widespread reform of the system of social welfare to address these evils. The report formed the basis for the post-war reforms known collectively as the welfare state, which included an expansion of National Insurance and the establishment of the National Health Service (Government of Denmark, 2000).

As part of the expansion of social welfare, the responsibility for secondary and 
tertiary care is placed on hospitals owned by the regions. General practitioners are private providers (self-employed) and are financed by the regions through a mixture of capitation and fee for service. The municipalities' main responsibilities are prevention, rehabilitation (outside hospitals) and home care. Health care at hospitals and general practitioners' offices is free at the point of service (Rudkjøbing, Strandberg-Larsen, Vrangbaek, Andersen, \& Krasnik, 2014: p. 2). Inflows of neoliberal ideas have been reflected in the Danish public sector since the 1980s and in a major structural reform in 2007; there is an increased focus on privatization and political efforts to make patients more "active consumers" in the health service system, which is to operate in more market-like terms. The introduction of neoliberal control technologies and consumer roles has increased the individualization of citizens' rights and responsibilities for their own health and sickness as patients (Holen, 2015: p. 41).

\section{Methodological Approach in Discourse Analysis}

Social constructivism is our overall approach to analysing the content of public health programmes to obtain a critical perspective on public health policy (Holstein \& Gubrium, 2008). This study applies a documentary analysis because it allows us to analyse the discourse in core governmental documents on the subject of overweight (Linders, 2008; Silverman, 2014). In general, documentary analysis is confronted by four essential scientific problems: 1) The selected data must be able to answer the research question; 2) Data sources are not equal, but instead are produced for different purposes, are directed to different audiences and are produced with different methodological constraints; 3) The relationship between the texts and reality and the inherent weaknesses and general accuracy of the documents must be evaluated; and 4) The analyst gives the documents voice, meaning that making sense of the data is especially important (Linders, 2008: p. 468). Drawing on discourse analysis, we argue that the language used in the selected reports represents a discursive technology that positions overweight pregnant women and health care professionals as particular subjects of government (Jørgensen \& Phillips, 2002). The concept of a discourse is included in the methodological guidelines of how to approach an area of research. Foucault defined discourse in the following way:

We shall call discourse a group of statements insofar as they belong to the same discursive formation; it does not form a rhetorical or formal unity, endlessly repeatable, whose appearance or use in history might be indicated (and, if necessary, explained); it is made up of a limited number of statements for which a group of conditions of existence can be defined. (Foucault, 1972b: p. 117).

The analysed documents represent different levels. The first two publications are traditional governmental publications, which reveal the political intentions of the public health system (Ministry of Health, 1999; Ministry of Interior Affairs and Health, 2002). The third publication is the result of collaboration between the governmental and scientific levels (National Institute for Public Health, 2007), and the fourth publication consists of recommendations for ma- 
ternity care practice (National Board of Health, 2013). See Table 1 for an overview of the materials used in the documentary analysis.

National public health programmes are considered an important part of Denmark's welfare and health policy. These programmes have an agenda-setting impact on the public debate and regional policy (Kamper-Jørgensen, 2004). We considered 1999 a suitable starting point because at that time, the Danish government highlighted lifestyle as a primary cause of Danish health problems. The discourse in the 1999 report represents a rhetorical shift towards the perception of lifestyle as a main causal factor in the development of disease and bodily deviation, which is one of our interests in this study. The included reports were identified through systematic information retrieval and a chaining search. We selected the extracts from the reports by reviewing the texts, searching for central statements and breaches in the discursive field.

The discourse analysis poses the following question: "How is it that one particular statement appeared rather than another?" (Foucault, 1972b: p. 27). In other words, the discourse analysis seeks to address the following question: How

Table 1. Public health reports analysed.

\begin{tabular}{|c|c|c|c|c|}
\hline & $\begin{array}{l}\text { The Governmental } \\
\text { Public Health } \\
\text { Programme 1999-2008 }\end{array}$ & $\begin{array}{l}\text { Healthy Throughout } \\
\text { Life-National Aims and } \\
\text { Strategies of Public } \\
\text { Health 2002-10 }\end{array}$ & $\begin{array}{l}\text { The Public Health } \\
\text { Report Denmark } \\
2007\end{array}$ & $\begin{array}{c}\text { Recommendations Concerning } \\
\text { Antenatal Care } 2013\end{array}$ \\
\hline $\begin{array}{l}\text { Decision-making } \\
\text { authority }\end{array}$ & $\begin{array}{l}\text { The social } \\
\text { democratic-led Danish } \\
\text { government adopted } \\
\text { this programme in } 2000 \text {. }\end{array}$ & $\begin{array}{l}\text { The liberal-led Danish } \\
\text { government published this } \\
\text { programme in } 2002 \text {. }\end{array}$ & $\begin{array}{l}\text { The liberal-led Danish } \\
\text { government and the } \\
\text { National Institute for } \\
\text { Public Health financed } \\
\text { this report in } 2007 .\end{array}$ & $\begin{array}{c}\text { The Danish National Board of } \\
\text { Health published these } \\
\text { recommendations in } 2009 \\
\text { and revised them in } 2013 \text {. } \\
\text { The Danish government was } \\
\text { liberal-led in } 2009 \text { and social } \\
\text { democratic-led in } 2013 \text {. }\end{array}$ \\
\hline Target audience & $\begin{array}{l}\text { Self-disciplined subjects } \\
\text { in primary schools, } \\
\text { workplaces, local } \\
\text { communities and the } \\
\text { health care system. }\end{array}$ & $\begin{array}{l}\text { Self-responsible participants } \\
\text { in health care } \\
\text { Psychosocially deprived } \\
\text { families, including the foetus } \\
\text { and the newborn child. }\end{array}$ & $\begin{array}{l}\text { Well-adapted citizens, } \\
\text { believed to behave } \\
\text { responsibly towards } \\
\text { the community. }\end{array}$ & $\begin{array}{l}\text { Pregnant women and their } \\
\text { families, health care leaders, } \\
\text { administrators, decision-makers } \\
\text { and personnel. }\end{array}$ \\
\hline $\begin{array}{l}\text { Expected } \\
\text { outcomes }\end{array}$ & $\begin{array}{c}\text { Diminution of social } \\
\text { inequality in health care. }\end{array}$ & $\begin{array}{l}\text { Prevention of prevalent } \\
\text { diseases and identified } \\
\text { risk factors. }\end{array}$ & $\begin{array}{l}\text { Increase in average } \\
\text { lifetime expectancy. } \\
\text { Diminution of lifestyle } \\
\text { diseases: lung cancer, } \\
\text { liver cirrhosis and } \\
\text { diabetes. }\end{array}$ & $\begin{array}{l}\text { Promotion of healthy } \\
\text { motherhood and childhood. }\end{array}$ \\
\hline $\begin{array}{l}\text { Recommended } \\
\text { governing }\end{array}$ & $\begin{array}{l}\text { Governing through } \\
\text { solidarity. } \\
\text { Autonomy-making } \\
\text { technologies }\end{array}$ & $\begin{array}{l}\text { Governing through solidarity. } \\
\text { Responsibility-making } \\
\text { technologies. } \\
\text { Governing through discipline } \\
\text { in psychosocially deprived } \\
\text { families. }\end{array}$ & $\begin{array}{l}\text { Governing through } \\
\text { solidarity. } \\
\text { Responsibility-making } \\
\text { technologies. } \\
\text { Autonomy-making } \\
\text { technologies. }\end{array}$ & $\begin{array}{l}\text { Governing through solidarity } \\
\text { and through discipline and } \\
\text { autonomy. }\end{array}$ \\
\hline
\end{tabular}


is reality produced by verbalizing it in exactly this way and with these concepts rather than in any other ways? An analysis of the discursive field reveals a statement in the exact specificity in which it occurs and its correlations with other connected statements. We address the following question: "What is this specific existence that emerges from what is said and nowhere else?" (Foucault, 1972b: p. 28).

Analysing the texts, we searched for groups of statements belonging to the same discursive formation and for patterns or connections between statements, ensuring that the contexts of the statements were represented accurately and meaningfully. Specifically, we searched for breaches in the discursive field concerning how overweight people were addressed. Inspired by the teachings of Prior (2004) on Foucauldian discourse analysis, we elaborated analytical questions that operationalized the concept of subjects. These questions allowed us to examine how overweight in pregnancy is understood and therefore, how 'truths' about the phenomenon are constituted and organized. Examples of these analytical questions include how categorizations, associations, assumptions and definitions describe actions to combat overweight in the health care system. The answer allowed us to capture the discursive patterns in public health reports on how overweight during pregnancy is made visible and therefore, manageable.

\section{Documentary Analysis of Public Health Reports}

Drawing on Rose's framework, we critically analyse official Danish public health policy during the period 1999-2013.

According to The Governmental Public Health Programme 1999-2008, governance should occur at the community level. The following settings are described as targets of preventive settings (Ministry of Health, 1999: p. 8): "primary schools", "workplaces", "local communities" and "the health care system". The subject is supposed to be socially engaged; "the active citizen" (Ministry of Health, 1999: p. 8) is constructed, and governing at a distance is rendered possible. Providing advice about "a sufficient and balanced diet" and "sufficient exercise" (Ministry of Health, 1999: p. 47) is recommended, as if one definitive approach to health were available. "Lifestyle counselling" and "support of persons with a specific risk of developing overweight" (Ministry of Health, 1999: p. 55) are mentioned as methods for the prevention of overweight without defining how that intervention should be planned. In this way of governing, freedom is regulated through individual responsibility concerning a person's own health, and an accomplishment of the self through a healthy lifestyle is established. To a considerable extent, the health professional's role rests upon governing through solidarity by invoking a spirit of community both in the general population and in antenatal care. Distinctions between the included and the excluded are created and are illustrated in the following quotation:

"The severely obese are at risk of discrimination, for instance related to the labour market... Hence it is crucial that the prevention is planned with the intention that any kind of social discrimination of the overweight persons is 
avoided." (Ministry of Health, 1999: p. 55)

The publication gives the impression of a view of health as an individual choice, exemplified in the following statements:

Our lifestyle is the cause-tobacco, alcohol, accidents, a fatty diet, and no or too little exercise. All these risk factors can be prevented. Although lifestyle is an individual choice, the authorities must clearly inform patients about what makes people ill and how illness can be prevented (Ministry of Health, 1999: p. 5).

According to Rose (1998), the key phrase in the institutional administration of individuals is "choose your way of life" (p. 160). This key phrase is meant as an indication of the type of self that is presupposed in institutional practices. According to the Foucauldian perspective, individual choice is tightly linked to neoliberal ideals and refers to a free and rational consumer in the market economy. Governing these autonomous individuals through their freedom is termed advanced liberalism (Rose, 1999: p. 84). This perspective grants ideological meaning to autonomy-making technologies that, if they have the desired effect, render a moralizing approach by the state superfluous. It is recommended that conduct should be promoted through an appeal to the rational, self-responsible, self-realized and self-disciplined subject, who participates in local communities (Ministry of Health, 1999: p. 8). The individual's normality is confirmed if the recommendations in the report are satisfied. The underlying meaning is that overweight pregnant women, having deviated from health norms, are denied the acknowledgement of normality by the authorities. This may constitute a basis for overweight pregnant women to perceive themselves in light of the insulting glances of others in the form of stigmatization and moral condemnation. In summary, this report addresses governing through solidarity and governing through autonomy in the general population. The recommended governing approach seems to work complimentarily, as the appeal to the autonomous pregnant woman works through community.

In Healthy Throughout Life-National Aims and Strategies of Public Health 2002-10, the focus is on self-responsible participants in health care. The appeal of this approach is reflected largely in its inclusiveness and allusions to shared goals: “... we all acknowledge our responsibility and take on our part of the duties..." (Ministry of Interior Affairs and Health, 2002: p. 4). The recommendation is that conduct should be promoted through the community by means of responsibility-making technologies (Ministry of Interior Affairs and Health, 2002: pp. 6-7). As Rose has expressed, government of the advanced liberal type produces subjects who regard themselves as free human beings (Rose, 2003: p. 183). The appeal to the sense of solidarity is intended to appeal to certain types of subjects who are capable of disciplining and controlling themselves and others. The punishing dimension in the community is also verbalized; "exclusion from the labour market, stigmatization and bullying" are mentioned (Ministry of Interior Affairs and Health, 2002: p. 21).

This publication includes a discussion of the recommended prophylactic effort in psychosocially deprived families. Because overweight is more frequently a 
health problem among persons of lower socioeconomic status, socioeconomic status is considered relevant to this problem. Intervention in these families should be strengthened, with the obvious goal being healthy children.

"A specific targeted intervention is needed, which includes early detection, treatment and support to prevent damage to the foetus and to secure care for the child after birth" (Ministry of Interior Affairs and Health, 2002: p. 52). The report highlights that psychosocially deprived families should be observed and controlled in heavy-handed ways to prevent damage to the foetus and neglect of the new born child. In this section of the publication, governing through discipline seems to be predominant. This report recommends governing through solidarity by means of responsibility-making technologies and governing through discipline. Although these forms of governing may seem to contradict one another, we argue that the responsibility-making and disciplining dimensions act together, with both being installed through the community.

The Public Health Report Denmark 2007 emphasizes that individual lifestyle factors are engaged in a complex interaction with social relationships, communities, living and working conditions and socioeconomic conditions in general (National Institute for Public Health, 2007: pp. 17-20). The focus on individually chosen lifestyle factors as determinants of public health is apparent. The following statement provides an example of the hegemonic discourse: "Several factors are of vital importance for public health. First, the individually chosen lifestyle and healthy habits, as well as biological and genetic factors, play a role" (National Institute for Public Health, 2007: p. 24). Concerning obesity, the report recommends intervening "at three levels: at the private level, at the community level and at the public level" (National Institute for Public Health, 2007: p. 27). It is noteworthy that the individual lifestyle and private levels are, naturally and consequently, mentioned first. This is exemplified in the following quotation:

"The Danish National Board of Health recommends intervention against obesity at three levels, the private level (meaning the individual, the domestic and the immediate vicinity), the community and the public level." (National Institute for Public Health, 2007: p. 269)

The three levels are analytically deconstructed in light of the concept of governmentality. The subject internalizes norms and rules in such a way that government by public policy, health ministry and health professionals extends "into" the person and therefore becomes decentralized. The distinction between the public and the private realms, between individuals and communities, is blurred. Another example of the intermingling of the individual and community levels is illustrated in the following quotation:

"Treatment of obesity demands lifelong intervention and control. The treatment is not just traditional medical treatment but also inter disciplinary pedagogic and psychological intervention with the purpose of creating a lifelong change in lifestyle. Obtaining permanent results demands strong engagement and willpower by the patient." (National Institute for Public Health, 2007: p. 271). 
In this quotation, it seems that the pedagogic and psychological intervention is entirely directed at individual will power, whereas the community level seems to be absent. We argue that this is an example of how government by public health policy becomes internalized in the person.

The report mentions certain groups with an increased risk of obesity: "Persons who participate in smoking cessation, persons treated with medications associated with weight gain, pregnant women, inactive or overweight children and grownups or persons with obesity in the family" (National Institute for Public Health, 2007: p. 267). Diseases related to lifestyle are indicated as the main causes of excess mortality among 35- to 74-year-olds, implying that under all circumstances, lifestyle is the most natural and genuine reason for the development of diseases.

The report states that psychosocial problems are common among people who are moderately overweight or obese, and this entails a considerably diminished quality of life. These problems may be the consequences of discrimination and bullying both in the labour market and in health care. "There is an increased incidence of low self-esteem, social isolation, depression and anxiety among obese persons" (National Institute for Public Health, 2007: p. 264). The dominant discourse in The Public Health Report Denmark 2007 is revealed in passages concerning the individually chosen lifestyle as the causal factor for disease and deviation from normality. Both responsibility- and autonomy-making technologies are predominant governmental technologies in relation to individual lifestyle choice. Both of these technologies are often related to governing through solidarity, as the well-adapted citizen is supposed to behave responsibly towards the community; to meet this expectation, the report recommends the activation of autonomy-making technologies.

In Recommendations Concerning Antenatal Care, the discourse on lifestyle during pregnancy is expressed in the following statements: "The midwife supports positive lifestyle change" (National Board of Health, 2013: p. 50) and "The midwife is supposed to support action to affect the pregnant woman's behaviour, or lifestyle change, to promote healthy motherhood and childhood. The midwife conducts a motivating dialogue concerning changes in lifestyle" (National Board of Health, 2013: p. 48). The midwife is supposed to take the initiative to begin group discussions on the subject of healthy lifestyle and on the possibilities of promoting health for the mother, child and entire family (National Board of Health, 2013: p. 50). Governing through solidarity is intended to establish a system of norms in favour of a healthy lifestyle, and this human technology attempts to maximize the subjects' capacity for health (Rose, 1998: p. 153). The above-outlined political thinking-regarding the individually chosen lifestyle as self-imposed-is extended in this publication.

Recommendations concerning obesity during pregnancy are addressed in a separate part of Recommendations Concerning Antenatal Care. The focus is almost entirely on the potential complications faced by overweight pregnant women, as exemplified in the following statement: 
Overweight pregnant women are offered advice to diminish weight gain and to perform physical activity. If the pre-pregnancy BMI is $\geq 27$, the woman is referred for a glucose tolerance test. If the BMI is $>35$, referral for an ultrasound scan to estimate presentation and foetal weight may be considered. Furthermore, severely obese women may be offered prophylactic epidural analgesia. (National Board of Health, 2013: p. 134)

In summary, Recommendations Concerning Antenatal Care extends the focus on the individually chosen lifestyle as self-imposed and the focus on overweight as an important risk factor during pregnancy.

\section{Discussion}

The aim of this article was to critically analyse official recommendations regarding how health professionals should govern overweight pregnant women and to discuss the implications for these women and their relationship with themselves. The three forms of governing were used as analytical tools to examine which form of governing was dominant and to analyse changes in governing over time. The three forms of governing were employed in the analysis to identify implications for the subjects. According to Dean (1999: p. 14), governing first produces new governance directed towards the population as the most crucial object of government; this approach uses new institutions and technologies, which are supposed to secure the health, wealth and happiness of the population. Second, the dominant tendency of governance in contemporary Western society is to govern individuals through their freedom, specifically, their freedom to make choices. Finally, governance expresses how the state has gradually shifted from a suppressive exercise of power to an exercise that seeks to form, inspire and motivate with a particular goal in mind. Villadsen (2007: p. 166) argues that we must examine the costs that governmental technologies impose on the subjects being governed and how the exercised power strives to establish new relationships, positions and organizations where classical governance seems to have been withdrawn.

The main finding of this study is that Danish public health programmes encourage governing through solidarity, including a palette of autonomy-making, responsibility-making and disciplinary technologies to govern people to promote physical health. This finding is apparently in opposition to Vallgårda's studies of public health; her conclusion is that appeals to behave responsibly directed towards the populations of Sweden and Denmark have essentially disappeared from health information. In recent decades, appeals to adopt responsible health habits have apparently shifted towards a more individualistic approach to health. Vallgårda argues that considerations of the social community have apparently yielded to individualistic interests (Vallgårda, 2003a: p. 268). However, this might be a matter of interpretation: how is the appeal, in this case of the individual overweight pregnant woman, motivated? Is the appeal to the overweight pregnant woman primarily to behave responsibly towards herself and her pregnancy, or is the appeal to behave in a manner that reflects her responsibility to 
the community? According to Rose's description of the active citizen as constituted through the exercise of free personal choice, the individualistic approach is inextricably associated with the community approach. This requires health policy to use technologies that govern subjects by promoting their social engagement. Contemporary political rationalities use a range of technologies that install a civilizing project by enhancing subjects' social commitment (Rose, 1998: p. 165).

The dominant discourse in the included programmes for overweight pregnant women is characterized by paternalistic advice about lifestyle. However, these programmes seem to devote inadequate attention to the pregnant woman's mastery of potentially contradictory feelings during pregnancy. The recommended authoritative conduct towards the pregnant women may be plausible, as some lifestyles have the potential to damage the foetus. It is interesting how pregnant women are granted autonomy to assimilate the recommendations into their lifestyles. The governance of lifestyle seems to occur through both disciplinary and autonomy-making technologies; health care professionals are supposed to combine these forms of governing, because the autonomy-making and disciplinary technologies seem to presuppose one another. Governing through discipline seeks to instil the desired health norms and works through the technologies of the self. Governing through autonomy functions by affecting the individual's ability to act in certain ways both by affecting the choices that an individual makes and by forming ideals. Taken at face value, governing through discipline might imply paternalistic advice, but according to Rose (1999), this type of conduct also addresses inner technologies (p. 78). As indicated in later parts of our article, it seems difficult to distinguish between these forms of governing because of the complexity of the concepts. More studies, examining whether health care professionals actually follow the official recommendations and whether they utilize the discursive strategies proposed in these recommendations, are needed.

The supposed consequences for the individual pregnant woman may be expressed in how subjects are formed by means of encouraging capacities and self-perceptions. The encouraged capacities are expressed as appeals to self-discipline and self-control, and the encouraged self-perception is expressed in the phrase "the active citizen" as a precondition for a healthy lifestyle. The perception of pregnancy is reoriented towards a disease, which is underlined by the discourse on obesity as a chronic condition (National Institute for Public Health, 2007: p. 261). Being categorized as a group with a disease may increase the risk of exclusion and stigmatization of vulnerable groups (National Institute for Public Health, 2007: p. 264). Recent empirical studies show that individuals with obesity in general, and pregnant women with obesity in particular, have a higher prevalence of depression, feelings of low self-esteem and stigmatization in their encounters with healthcare professionals (Lindhardt et al., 2013; Malterud \& Ulriksen, 2011). Stigmatization in general creates a gap in social identity, selfawareness and perception by others (Goffman, 1963). Furthermore, the catego- 
rization of obese pregnant women as a group with a disease alters health care professionals' approach to these women, who are no longer addressed as a group experiencing a normal life process. In Recommendations Concerning Antenatal Care, the shift in discourse concerning the overweight pregnant woman is represented as advice concerning weight gain, physical activity and access to further medical and visual examinations (National Board of Health, 2013: p. 134). For the overweight pregnant woman, this implies that the perception of pregnancy, childbirth and the formation of a family has become a potentially complicated process. This might imply that the overweight pregnant woman becomes less confident in her capacity to experience a normal life process. Public health programmes conjure an image of overweight individuals as strongly burdened subjectivities, who in all cases require authoritative governing. This image does not harmonize with the image of the active and self-responsible citizen invoked by public health reports. A dilemma between the recommended authoritative governing and the created image of the target group is revealed. This indicates a certain ambivalence in the hegemonic discourse on overweight concerning how to address overweight pregnant women. Should they be addressed as burdened subjectivities or as active and self-responsible human beings? The image on which health professionals base their governance of overweight pregnant women is also an aspect of the supposed consequences for this group of pregnant women. Do they govern based on an image of pregnant women as rational users of health care? Alternatively, do they utilize moralizing methods, which act in opposition to that intention? If governing based on an image of overweight pregnant women as active self-responsible citizens is implemented, how does this image respond to the produced image of the overweight segment of the population as individuals in need of authoritative governing? According to Rose, the image of the enterprising self is a premise of neoliberalism that has the following implication: "Good government is to be grounded in the ways in which people govern themselves" (Rose, 1998: p. 154). From this perspective, the central point is how governing professionals become conscious of how people govern themselves.

The focus of this article is the discourses in official documents; hence, there is a need to advance such research and investigate how the health care practice is administered. Specifically, it is relevant to study health care professionals' awareness of the implications of their role for the target groups in public health and to study how pregnant women are categorized in their encounters with health care professionals.

The methodological weaknesses of this analysis concern challenges in distinguishing among the three forms of governing caused by the complexity and overlap of the concepts. An example is when governing through solidarity is produced because it appeals to certain types of subjects who are capable of disciplining and controlling themselves and others. This example illustrates how governing through solidarity simultaneously addresses governing through discipline and governing through autonomy. Furthermore, governing through disci- 
pline acts through the technologies of the self in the sense that the autonomy-making and self-disciplining technologies are part of individual governing (Rose, 1999: p. 78).

We have attempted to counter the inherent weakness of the discourse analysis as a loosely structured methodology by including extracts from the documents to exemplify how the discourses are constructed and interrelated in these documents to facilitate transparency. Furthermore, to critically assess the sharpness of this analysis, one should also consider the nature of the types of documentsfor example, who the authors of the documents are, what interests they represent, who the target group is and how this affects how the documents are assumed to affect health professionals and their attitudes and behaviour towards obese pregnant women. The scientific sector formed a major part of The Public Health Report Denmark 2007, in contrast to the other reports considered here, which were more political in origin. The 2007 report is grounded in the scientific sector, represented by The National Institute of Public Health in Denmark. That report refers to quantitative materials to a greater degree than the other reports that we consider, and we argue that these conditions influence the discourse on overweight pregnant women. As indicated in earlier parts of the article, the discourses on overweight in pregnancy focus on the physical aspects of overweight and obesity. Furthermore, the 2007 report states that psychosocial problems are common among people with moderate overweight or obesity and that this entails a considerably diminished quality of life. The discourse concerning the overweight and obese population is posed as an indisputable fact supported by scientific statements. These discourses might have a greater impact on attitudes among health care professionals because of their scientific framework. Furthermore, we consider whether the target audience of the reports affected the public health discourse. In the first three documents (listed in Table 1), the target audience is the general population of Denmark at risk of developing overweight or obesity; in the fourth document, the target audience is pregnant women in Denmark. The audience seems to be addressed according to the recommended form of governing and the applied technology. Governing through solidarity addresses the general population; however, when the focus is on the pregnant part of the population, this way of governing also includes disciplinary technologies.

\section{Conclusion}

In the last decade, public health programmes have primarily encouraged governing through solidarity, including a palette of autonomy-making, responsibility-making and disciplinary technologies to govern overweight pregnant women to promote physical health. For overweight pregnant women, being categorized as part of a diseased group may increase the risk of exclusion and stigmatization. Furthermore, the categorization of a diseased group alters health care professionals' approach to overweight pregnant women, who are no longer addressed as a group experiencing a normal life process. The long-range effects of the re- 
commended governing approach include, on the one hand, the development of new subjectivities engaged in interest and patient groups for overweight persons in society. On the other hand, the effects might include the threat of exclusion from social citizenship and other forms of stigmatization of the abovementioned groups.

Further research is recommended in the form of empirical qualitative studies of governmental technologies and technologies of the self that target overweight pregnant women and health care professionals.

\section{Funding}

This research received no specific grants from any funding agency in the public, commercial, or not-for-profit sectors.

\section{References}

Campbell, F., Johnson, M., Messina, J., Guillaume, L., \& Goyder, E. (2011). Behavioural Interventions for Weight Management in Pregnancy: A Systematic Review of Quantitative and Qualitative Data. BMC Public Health, 11, 491. https://doi.org/10.1186/1471-2458-11-491

Danish Association of Obstetrics and Gynaecology (DSOG). (2012). Overweight Pregnant Woman. Sandbjerg: Obstetrical Guideline.

Dean, M. (1999). Governmentality. Power and Rule in Modern Society. London: Solid Action on Globalization and Environment.

Foucault, M. (1972a). Truth and Power. In C. Gordon (Ed.), Power/Knowledge (pp. 109-133). New York, NY: Pantheon Books.

Foucault, M. (1972b). The Archaeology of Knowledge (A. M. Sheridan Smith, Trans.). London: Tavistock Publications.

Foucault, M. (1982). The Subject and Power. Critical Inquiry, 8, 777-795. https://doi.org/10.1086/448181

Foucault, M. (1988). Technologies of the Self. In L. H. Martin, H. Gutman, \& P. H. Hutton (Eds.), Technologies of the Self: A Seminar with Michel Foucault (pp. 16-49). Amherst, MA: University of Massachusetts Press.

Furber, C. M., McGowan, L., Bower, P., Kontopantelis, E., Quenby, S., \& Lavender, T. (2013). Antenatal Interventions for Reducing Weight in Obese Women for Improving Pregnancy Outcome. Cochrane Database of Systematic Reviews, 1, CD009334. https://doi.org/10.1002/14651858.CD009334.pub2

Goffman, E. (1963). Stigma: Notes on the Management of Spoiled Identity. Englewood Cliffs, NJ: Prentice-Hall.

Gordon, C. (1991). Governmentality. In G. Burchell, C. Gordon, \& P. Miller (Eds.), The Foucault Effect. Studies in Governmentality (pp. 87-104). Chicago, IL: Chicago University Press.

Government of Denmark (2000). Denmark as a Pioneering Country-A Sustainable System of Pensions. Copenhagen: The Ministry for Economic Affairs and the Interior.

Holen, M. (2015). Involving Patients as Politics: How Did It Become Possible and What about It? In Theme: Health and Health Politics in the Welfare State. Gjallerhorn (Vol. 20, pp. 37-48). Aarhus: VIA University College.

Holstein, J. A., \& Gubrium, J. F. (2008). Handbook of Constructionist Research. London: Guilford Press. 
Jørgensen, M. W., \& Philips, L. J. (2002). Discourse Analysis as Theory and Method. Thousand Oaks, CA: SAGE Publications Ltd. https://doi.org/10.4135/9781849208871

Kamper-Jørgensen, F. (2004). National Public Health Programmes in the Nordic Countries. Journal of the Danish Medical Association, 166, 1301-1305.

Linders, A. (2008). Documents, Texts, and Archives in Constructionist Research. In J. A. Holstein, \& J. F. Gubrium (Eds.), Handbook of Constructionist Research (pp. 467-490). London: Guilford Press.

Lindhardt, C. L., Rubak, S., Mogensen, O., Lamont, R. F., \& Joergensen, J. S. (2013). The Experience of Pregnant Women with a Body Mass Index $>30 \mathrm{~kg} / \mathrm{m}^{2}$ of Their Encounters with Healthcare Professionals. Acta Obstetricia et Gynecologica Scandinavica, 92, 1101-1107. https://doi.org/10.1111/aogs.12186

Malterud, K., \& Ulriksen, K. (2011). Obesity, Stigma, and Responsibility in Health Care: A Synthesis of Qualitative Studies. International Journal of Qualitative Studies on Health and Well-Being, 6. https://doi.org/10.3402/qhw.v6i4.8404

Ministry of Health (1999). The Governmental Public Health Programme 1999-2008. Copenhagen: Ministry of Health.

Ministry of Interior (2002). Affairs and Health. In Healthy throughout Life-National Aims and Strategies of Public Health 2002-10. Copenhagen: Ministry of Interior Affairs and Health.

National Board of Health (2006). Methods and Means to Prevent Overweight. Experience from 26 Projects Illustrated from Different Perspectives. Copenhagen: National Board of Health.

National Board of Health (2013). Recommendations Concerning Antenatal Care. Copenhagen: Committee of Health Information.

National Institute for Public Health (2007). The Report of Public Health (Denmark): 2007. Copenhagen: University of Southern Denmark.

Perron, A., Rudge, T., \& Holmes, D. (2010). Citizen Minds, Citizen Bodies: The Citizenship Experience and the Government of Mentally Ill Persons. Nursing Philosophy, 11, 100-111. https://doi.org/10.1111/j.1466-769X.2010.00437.x

Prior, L. (2004). Following in Foucault's Footsteps. Text and Context in Qualitative Research. In S. Hesse-Biber, \& P. Leary (Eds.), Approaches to Qualitative Research: A Reader on Theory and Practice (pp. 317-333). New York, NY: Oxford University Press.

Rahman, M. M., Abe, S. K., Kanda, M., Narita, S., Rahman, M. S., Bilano, V., Ota, E., Gilmour, S., \& Shibuya, K. (2015). Maternal Body Mass Index and Risk of Birth and Maternal Health Outcomes in Low- and Middle-Income Countries: A Systematic Review and Meta-Analysis. Obesity Reviews, 16, 758-770. https://doi.org/10.1111/obr.12293

Rose, N. (1998). Inventing Ourselves. Psychology, Power and Personhood. Cambridge: Cambridge University Press.

Rose, N. (1999). Powers of Freedom. Reframing Political Thought. Cambridge: Cambridge University Press. https://doi.org/10.1017/CBO9780511488856

Rose, N. (2003). Governing Freedom-An Analysis of Political Power in Advanced Liberal Democracies. In C. Borch, \& L. L. Larsen (Eds.), Power: Perspective and Government. Luhmann and Foucault at Discussion (pp. 180-199). Copenhagen: Hans Reitzel.

Rudkjøbing, A., Strandberg-Larsen, M., Vrangbaek, K., Andersen, J. S., \& Krasnik, A. (2014). Health Care Agreements as a Tool for Coordinating Health and Social Services. International Journal of Integrated Care, 14, e036. https://doi.org/10.5334/ijic.1452

Schneider, A. L., \& Ingram, H. (2008). Social Constructions in the Study of Public Policy. 
In J. A. Holstein, \& J. F. Gubrium (Eds.), Handbook of Constructionist Research (pp. 189-211). London: Guilford Press.

Silverman, D. (2014). Interpreting Qualitative Data. Methods for Analyzing Talk, Text and Interaction. London: SAGE Publications.

Vallgårda, S. (2003a). Public Health as Policy. Denmark and Sweden from 1930 until Today. Aarhus: Aarhus University Press.

Vallgårda, S. (2003b). Studies of Exercise of Power. Contribution to an Operationalization of Michel Foucault's Concept of Governmentality. In P. M. Christiansen, \& L. Togeby (Eds.), Traces of Power (pp. 117-131). Aarhus: Aarhus University Press.

Villadsen, K. (2007). Power and Self-Technology. Foucault's Relevance for Current Welfare Studies? Journal of Research in Welfare, 10, 156-167.

Submit or recommend next manuscript to SCIRP and we will provide best service for you:

Accepting pre-submission inquiries through Email, Facebook, LinkedIn, Twitter, etc. A wide selection of journals (inclusive of 9 subjects, more than 200 journals)

Providing 24-hour high-quality service

User-friendly online submission system

Fair and swift peer-review system

Efficient typesetting and proofreading procedure

Display of the result of downloads and visits, as well as the number of cited articles

Maximum dissemination of your research work

Submit your manuscript at: http://papersubmission.scirp.org/

Or contact aasoci@scirp.org 